\title{
ДИСКУССИИ
}

DOI: https://doi.org/10.15688/jvolsu2.2020.2.14

UDC 81'373.23

Submitted: 20.02.2019

LBC 81.053 .2

Accepted: 31.01 .2020

\section{COGNITIVE POTENTIAL DEVELOPMENT OF PRECEDENT ANTHROPONYM}

\author{
Mikhail V. Zolotarev \\ Saratov State University named after N.G. Chernyshevsky, Saratov, Russia \\ Irina V. Privalova \\ Saratov State Medical University named after V.I. Razumovsky, Saratov, Russia
}

\begin{abstract}
The article discusses the dynamics of the cognitive potential development of the precedent anthroponym, i.e. a nationally and culturally marked proper name that reflects discursive and pragmatic trends in the evolution of a single language unit within a fixed time frame. The analysis of the data of lexicographic sources along with the data of discourse practices and the psycholinguistic experiment has helped the authors to identify the distinctive features of such lingua-mental phenomenon as the precedent anthroponym. Also, the main types of the transformations that contribute to further development of cognitive potential of the precedent anthroponym have been described. The fact that the differential characteristics of a proper name comprise the perceptual invariant of the precedent anthroponym is of outmost importance. The connection of the precedent anthroponym with some additional knowledge ensures its successful functioning. Hence, one more unique peculiarity of the cognitive potential of the precedent anthroponym is the possibility of conceptual evolution that results in the formation of a new meaning. So, it has been proved that the cognitive potential of the precedent anthroponym enables this linguistic unit to go through several stages of its possible conceptual development in discursive practice: the stage of denotative use, the stage of connotative use, the stage of the external form transformation (word-formation and deonymic conversion), the stage of metaphorization and metonymy, the stage of phraseologization and idiomatization, and the stage of a word play. The results of the study create awareness about the mechanism of secondary conceptualization of knowledge and make a contribution to the development of modern cognitive linguistics.
\end{abstract}

Key words: anthroponym, precedent anthroponym, cognitive potential, secondary conceptualization, conceptual development, transformation.

Citation. Zolotarev M.V., Privalova I.V. Cognitive Potential Development of Precedent Anthroponym. Vestnik Volgogradskogo gosudarstvennogo universiteta. Seriya 2. Yazykoznanie [Science Journal of Volgograd State University. Linguistics], 2020, vol. 19, no. 2, pp. 159-170. (in Russian). DOI: https://doi.org/10.15688/jvolsu2.2020.2.14

\section{РАЗВИТИЕ КОГНИТИВНОГО ПОТЕНЦИАЛА ПРЕЦЕДЕНТНОГО АНТРОПОНИМА}

\section{Михаил Владимирович Золотарев}

Саратовский национальный исследовательский государственный университет им. Н.Г. Чернышевского,

г. Саратов, Россия 


\section{Ирина Владимировна Привалова}

Саратовский государственный медицинский университет им. В.И. Разумовского, г. Саратов, Россия

Аннотация. Статья посвящена рассмотрению динамики когнитивного потенциала прецедентного антропонима, национально и культурно маркированного имени собственного, отражающего дискурсивно-прагматические тенденции в эволюции отдельной языковой единицы на фиксированном временном отрезке. На основе материалов лексикографических источников, примеров из разных типов дискурса и результатов психолингвистического эксперимента выявлены отличительные черты организации такого лингвоментального комплекса, как прецедентный антропоним, и описаны основные типы трансформаций, которые способствуют дальнейшему развитию его когнитивного потенциала. Отмечено существование инварианта восприятия прецедентного антропонима, который характеризуется наличием дифференциальных признаков имени собственного. Установлено, что условием функционирования прецедентного антропонима является его связь с дополнительной совокупностью знаний. Показано, что особенностью когнитивного потенциала прецедентного антропонима является возможность концептуального развития с последующим формированием нового значения. Обнаружено, что когнитивный потенциал прецедентного антропонима может быть реализован в несколько этапов, отражающих потенциальную концептуальную эволюцию языковой единицы в дискурсивной практике: денотативное употребление; коннотативное употребление; преобразование внешней формы (словообразование, деонимическая конверсия); метафоризация и метонимизация; фразеологизация и идиоматизация; языковая игра. Результаты исследования способствуют уточнению действия механизма вторичной концептуализации знаний и вносят вклад в развитие современной когнитивной лингвистики.

Ключевые слова: антропоним, прецедентный антропоним, когнитивный потенциал, вторичная концептуализация, концептуальное развитие, трансформация.

Цитирование. Золотарев М. В., Привалова И. В. Развитие когнитивного потенциала прецедентного антропонима // Вестник Волгоградского государственного университета. Серия 2, Языкознание. - 2020. T. 19, № 2. - C. 159-170. - DOI: https://doi.org/10.15688/jvolsu2.2020.2.14

\section{Введение}

Среди всех прецедентных феноменов прецедентные антропонимы являются самыми частотными по использованию в различных видах дискурса. Выделяют имена реально существовавших и существующих личностей и антропонимы, появившиеся в результате креативной деятельности человека (в частности в сферах литературы, живописи, фольклора архитектуры, кино и телевидения, рекламы и т. д.). Имена литературных героев, героев кинофильмов, сериалов, рекламных роликов не менее известны, чем имена политиков, актеров, художников, например: Геракл, Цезарь, Джоконда, Доктор Хаус, Леня Голубков, Шрек, Гарри Поттер и т. д. УПотребительность прецедентных антропонимов объясняется лингвистическими особенностями имен собственных, которые отражают специфику модели образования концептуальных знаний. Быть источником дополнительных концептуальных знаний, развивать имеющийся когнитивный потенциал - это свойства концепта, представленного такой языковой единицей, как имя собственное.
По мнению Т.Ю. Лариной и Т.В. Милевской, «широкие функциональные возможности онима обусловлены его различными модальными характеристиками, ассоциативными связями, соотнесенными с реализацией конкретного образа» [Ларина, Милевская, 2015, с. 115]. Полагаем, что концепт, который вербализуется прецедентным именем, имеет более значительный потенциал генерирования новых значений, чем концепт прецедентной ситуации или прецедентного высказывания. При этом имена собственные не менее информативны, чем имена нарицательные, от которых их отличают особые принципы номинации и механизмы концептуализации знаний.

Имена собственные выступают антропоцентрическими маркерами языка, что и отражено во внутренней форме термина «антропоним»: «...одним из важнейших рубежей на пути становления человека разумного (homo sapiens) стало возникновение имени собственного как итога формирования человеческой личности» [Терещенко, 2016, с. 76].

Основным назначением языковых единиц является вербальная репрезентация предметов и понятий окружающей действительнос- 
ти. При восприятии человеком реальных предметов и понятий «запускается» действие механизма первичной концептуализации, а при общении и получении языковой информации актуализируется процедура вторичной концептуализации. Понятие «концепт» применимо по отношению к смыслам, которые возникают у носителя языка в процессе мышления, так как «каждый человек является носителем индивидуальной концептуальной системы» [Волкова, 2017, с. 208]. При этом совокупность знаний, стоящих за словом, не является универсальной. Во-первых, существуют языковые единицы, обозначающие уникальные предметы и понятия, например, имена собственные. В данном случае, вероятно, следует говорить об исключительной совокупности знаний об отдельных индивидах. Во-вторых, «кванты знания» как итог когнитивной деятельности могут быть национально и культурно обусловлены (в частности, представления о доме не совпадают у представителей англо- и русскоязычной культур). В-третьих, некая совокупность знаний об объекте может приобретать дополнительные смыслы в процессе функционирования языковой единицы в конкретном социуме на конкретном временном отрезке, то есть в определенных прагматических и дискурсивных обстоятельствах. Тогда наиболее актуальным становится предложенное Е.С. Кубряковой толкование концепта как посредника между языковыми единицами и экстралингвистической действительностью, при этом значение слова не может быть сведено к образующим его концептам [Кубрякова, 1997, с. 92]. Данная формулировка раскрывает суть оформления когнитивного пространства таких явлений, как прецедентные феномены. Особый интерес представляет рассмотрение динамики когнитивного потенциала прецедентного антропонима, поскольку это национально и культурно маркированное имя собственное, отражающее дискурсивно-прагматические тенденции в эволюции отдельной языковой единицы на фиксированном временно́м отрезке.

\section{Методика исследования}

Изучение имен собственных имеет давние традиции и определенные успехи в пост- роении теоретической базы и разработке уникальных методов исследования. Имена собственные рассматриваются в лингвистическом, этнолингвистическом, историческом, peгиональном, диалектологическом, культурном, прагматическом, этимологическом и многих других аспектах. При этом исследования, выполненные в русле прецедентной ономасиологии, немногочисленны, а анализ эволюции когнитивного потенциала антропонима предпринимается впервые. Цель статьи заключается в выявлении специфики когнитивного потенциала прецедентного антропонима, особенностей его развития в различных прагматических условиях. Для этого охарактеризованы отличительные признаки такого лингвоментального комплекса, как прецедентный антропоним, и описаны основные типы его трансформаций, происходящих в реальных условиях общения и способствующих дальнейшему развитию когнитивного потенциала прецедентного антропонима.

Для выявления отличительных признаков прецедентного антропонима были отобраны 453 англоязычные и русскоязычные языковые единицы (256 и 197 соответственно). Они составили эмпирическую базу исследования, в которую вошли прецедентные антропонимы, зафиксированные в лексикографических источниках, в примерах из дискурсов различных видов и в реакциях информантов - участников психолингвистического эксперимента. В качестве источника для сплошной выборки использованы лингвострановедческие словари «Американа», «Жизнь и культура США», «Русское культурное пространство. Лингвокультурологический словарь», «Dictionary of Cockney Rhyming Slang», а также материалы электронного словаря «Urban Dictionary». Было проанализировано функционирование прецедентных антропонимов в литературном, разговорном, масс-медийном, электронном, теле- и кинодискурсах. Исследование проведено на материале русского и английского языков, что позволило продемонстрировать универсальный характер механизма развития когнитивного потенциала прецедентного антропонима.

Для наблюдения за формированием когнитивного пространства антропонима в разговорной речи были рассмотрены ответы ис- 
пытуемых, полученные в результате двухэтапного психолингвистического эксперимента (часть материалов которого была описана при изучении лингвопрагматических особенностей прецедентных феноменов в современном молодежном дискурсе, см.: [Золотарев, 2017]). На первом этапе эксперимента были выявлены наиболее частотные сферы-источники прецедентных антропонимов: популярная музыка, литература, Библия, кино, телевидение. Затем была составлена анкета, которую респонденты могли заполнить, в том числе и в режиме онлайн. В анкете было предложено десять слов-стимулов, отобранных из 453 единиц, входящих в эмпирическую базу. Они представляют собой известные антропонимы из пяти сфер-источников. Выбор слов-стимулов обусловлен предположением о том, что антропонимы, самые частотные в поисковой сети Интернет, являются наиболее релевантными для представителей определенной этнолингвокультуры. Сначала респондентам были предъявлены модельные предложения с прецедентными антропонимами, а затем дано задание, в котором их просили написать свои примеры со словами-стимулами. Анкетирование прошли 200 респондентов (в равных пропорциях для русского и английского языков) в возрасте от 18 до 30 лет. Эксперимент проводился с февраля 2014 по июнь 2015 года. Респондентами выступали студенты американских и российских вузов. Основанием для экспериментального исследования послужило предположение, что в отличие от других видов дискурса, в разговорном дискурсе наблюдается наиболее динамичное развитие концептуального пространства антропонима, поскольку в разговорной речи отражаются особенности процессов индивидуализации и социализации носителя языка.

\section{Результаты и обсуждение}

Прежде чем характеризовать механизм развертывания когнитивного потенциала прецедентного антропонима, важно установить отличительные признаки данного лингвоментального комплекса. В.В. Красных отмечает, что прецедентное имя представляет собой сложный знак, при употреблении которого апеллируют не к денотату, а к его дифферен- циальным признакам [Красных, 2003, с. 172]. Последние для имени собственного играют роль дополнительных квантов информации о субъекте. Например, имя собственное Paul Bunyan не отличается от других типичных англоязычных имен, но дифференциальные признаки образуют его когнитивное пространство и формируют уникальную совокупность знаний о национальном фольклорном герое: «Баньян Пол, легендарный великан-лесоруб, по преданию живший в северных лесах США и Канады. Постоянным спутником Пола был голубой бык по имени Бейб (Babe). В одной из легенд говорится, что заполненные водой следы Пола и Бейба образовали десять тысяч озер Миннесоты» (Жизнь и культура США, c. 57). Отличительной характеристикой персонажа, чье имя стало прецедентным, является безграничная сила, что и нашло отражение, например, в названии одной из военных операций “Operation Paul Bunyan” или в рекламном объявлении: State looking for Paul Bunyan - like people to chop trees (подробно см: [Привалова, 2005, с. 238]). Выскажем предположение, что в структуре концепта имени вымышленного персонажа содержится больше информационных «квантов», маркирующих данный концепт, чем в структуре концепта имени реальных людей. Прецедентный антропоним Paul Bunyan обозначает мифологизированный прототип, факт вневременной актуальности которого подтверждает недавняя постановка одноименного мюзикла. О популярности этого культурного события свидетельствуют непрекращающиеся дискуссии с СМИ: What on ear this Britten's Paul Bunyan? A satire on capitalism? A New World response to Soviet-style social realism? (The Guardian, 2018).

В прецедентном антропониме реализуется возможность концептуального слияния нескольких концептов с последующим формированием нового значения. По словам В.В. Красных, «прецедентное имя может состоять из одного или нескольких элементов, обозначая при этом одно понятие» [Красных, 2003 , с. 172]. Например, имя собственное Алиca репрезентирует нечетко оформленный объем концептуального содержания, но словосочетание Лиса Алиса обозначает вполне конкретный образ с определенным набором 
характеристик, широко известных носителям языка. Аналогичное утверждение верно и по отношению к таким прецедентным именам, как папа Карло, дядя Ваня, матрос Железняк, мать Тереза и т. д. Слово јudge имеет иной смысл, чем Judge Dredd - суровый спаситель мира из комиксов: Dredd is the most famous and feared of the Judges in Mega City One, and is considered hard but fair. Has saved the world numerous times in the comics (Urban Dictionary).

Как отмечается во вступительной статье к лингвокультурологическому словарю «Русское культурное пространство», условием функционирования прецедентного антропонима является его связь с дополнительной совокупностью знаний, так как кроме первичного концептуального знания он содержит комплементарную информацию вследствие своей связанности с широко известным текстом, ситуацией. Так, прецедентное имя Scarlett O'Hara апеллирует к известному роману "Gone With the Wind" и не менее известному изречению главной героини: There will be another day. Имя Lone Ranger принадлежит персонажу американского вестерн-сериала. Неустрашимому борцу за справедливость помогают друг-индеец Тонто и верный конь Силве (Американа, с. 543). Многие фразы из сериала, который транслировался на протяжении почти пятнадцати лет, стали частью американского фольклора: Hi yo Silver Away!; Who is that masked man? (Жизнь и культура США, с. 224). Сюжет оказался настолько популярным, что в 2013 г. был выпущен ремейк фильма, который актуализировал связанные с оригиналом прецедентные явления. Развитие вторичного концептуального знания имеет универсальный характер и может быть представлено следующим образом: имя - произведение - ситуация - высказывание - артефакт (в случае с Lone Ranger артефактами являются серебряная пуля, маска). Следовательно, реализуется такая особенность прецедентного антропонима, как способность создавать вокруг себя сложное концептуальное пространство. Аналогичную динамичную структуру концептуального пространства вокруг прецедентного антропонима можно проследить и на русскоязычном материале. Например, прецедентное имя
Емеля связано с прецедентным высказыванием по щучьему велению, по моему хотению и прецедентными артефактами - движущейся печью и щукой.

Включение имени собственного в событие, которое в силу ряда причин стало общеизвестным, может сопровождаться появлением нового концепта. Например, Miranda rule означает конституционное право подозреваемого на молчание и предоставление адвоката (Американа, с. 602): Appeal court says detention of Miranda was law ful but clause under which he was held is incompatible with European human rights convention (The Guardian, 2016).

Дериватами выступают такие словосочетания, как Pre-Miranda silence или Miranda violations, которые понятны без объяснений любому представителю англоязычного сообщества. Прецедентные антропонимы культурно специфичны, так как когнитивная база носителей языка содержит инвариант восприятия, то есть «совокупность дифференциальных признаков, которая хорошо известна всем членам определенного этнолингвокультурного сообщества» [Прецедентное имя..., 1997, с. 84].

Любой прецедентный антропоним аксиологически детерминирован. В набор дифференциальных характеристик входят положительно или отрицательно маркированные признаки, например, имя Мавроди употребляется с негативной коннотацией. Оно соотносимо с такими понятиями, как мошенничество и обман. Положительные или отрицательные характеристики, приписываемые реально существовавшему лицу, мифологизируются, а прецедентный антропоним выступает в качестве символа: мать Тереза символизирует самопожертвование, Золушка - трудолюбие и скромность, Бонни и Клайд - жажду легкой наживы и жестокость, Гобсек-скупость, Ocman Бендер - авантюризм.

Характеристикой прецедентного антропонима становится связанное с ним прецедентное высказывание, например: I cannot tell a lie; First in war, first in peace, and first in the hearts of his countrymen, авторство которых приписывается Дж. Вашингтону (Жизнь и культура США, с. 385), призваны мифологизировать его образ. В отдельных случаях иде- 
ализация прецедентных антропонимов с отрицательными коннотациями вызывает неоднозначную реакцию носителей языка: The Province of British Columbia had another challenge in this year of reconciliation: there is the name of Justice Matthew Begbie (18191894), the "hanging judge", attached to a statue in New Westminster and a plaque in Victoria as well as a couple of streets. He got this epithet because of his role in the hanging of six Tsilhqot'in chiefs in 1864 [Schaarschmidt, 2018, c. 183-184].

Описав отличительные признаки прецедентного антропонима, рассмотрим основные типы трансформаций, которые способствуют развитию его когнитивного потенциала. Они были выявлены в результате анализа данных, полученных при проведении психолингвистического эксперимента, который позволил проследить некоторые закономерности употребления прецедентных антропонимов в дискурсе носителей английского и русского языков. Для анализа были выбраны десять языковых единиц, которые обладают набором признаков, позволяющим квалифицировать их как прецедентные антропонимы (пять русскоязычных и пять англоязычных): Буратино и Tom Sawyer (сфера-источник «Литература»); Tuмати и Eminem (сфера-источник «Популярная музыка»); Aдам и Eвa, Adam and Eve (сфера-источник «Библия»); Владимир Познер и Jon Stewart (сфера-источник «Телевидение»); Штирлии и James Bond (сфера-источник «Кино»). Как видим, эти единицы репрезентируют прецедентные имена, которые вполне соотносимы по своему денотативному наполнению и функциям. Эти прецедентные имена были отмечены наибольшим количеством упоминаний в Сети на момент проведения эксперимента, а значит, являются наиболее релевантными для носителей русской и английской лингвокультур.

Результаты эксперимента показали, что в дискурсивной практике специфические признаки когнитивного потенциала прецедентного антропонима обусловливают его концептуальное развитие в несколько этапов: 1) денотативное употребление; 2) коннотативное употребление (подробно о них см.: [Гудков, 1998]); 3) преобразование внешней формы (словообразование и деонимическая конвер- сия); 4) фразеологизация и идиоматизация; 5) метафоризация и метонимизация; 6) языковая игра.

1. Этап денотативного употребления. Денотативное употребление прецедентного антропонима сводится к тому, что имя собственное используется для обозначения своего обычного референта, например: Папа Карло выстрогал Буратино из полена; Donald Duck helped Wise Little Hen to plant her corn; Jon Stewart makes me smile. Когнитивный потенциал прецедентных единиц, хранящихся в коллективной памяти лингвокультурного сообщества, находит минимальное эксплицитное развитие. Эксплицитно выражается только сумма номинальных общеизвестных знаний: Буратино - герой сказки; Donald Duck - герой мультфильма; Jon Stewart - ведущий американского телевидения. Денотативное употребление представляет собой базовый этап подготовки развития сконцентрированных в прецедентном антропониме знаний.

2. Этап коннотативного употребления. Развитие когнитивного потенциала прецедентного антропонима на данном этапе позволяет говорить о наличии у рассматриваемой единицы особой когнитивной структуре, которая выражается с помощью: а) ряда дифференциальных признаков; б) ряда атрибутов; в) аксиологического вектора (оценки) [Гудков, 1998, с. 84]. Согласно Д.Б. Гудкову, в коллективном когнитивном пространстве содержатся минимизированные представления о «культурных предметах», отражающиеся в ограниченном наборе дифференциальных признаков той или иной прецедентной единицы [Гудков, 1998, c. 86].

Рассмотрим дифференциальные признаки прецедентных имен Адам и Ева, Adam and $E v e$ на материале предложений, составленных респондентами. Русскоязычные респонденты, как правило, используют прецедентные име-

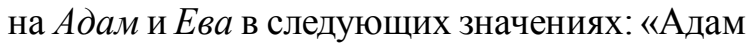
и Ева - мужчина и женщина, поддавшиеся искушению» (38 \%); «Адам и Ева - первые обитатели Земли» (19\%); «Адам и Ева - нагие люди» (19\%) (в процентах указано количество полученных ответов на конкретный стимул по отношению к общей сумме всех реакций). Для русскоязычных респондентов ядерными явля- 
ются такие признаки Адама и Евы, как 'беспомощность перед искушением', 'нагота', 'первоначальность', а периферийными 'влюбленность' (6 \%), ‘глупость' (6 \%), ‘генетическая связь' (Ева была создана из ребра Адама - $6 \%$ ), 'предначертание быть наказанными' (6 \%), так как частотность их употребления низкая. Для англоязычных респондентов ядерными являются только два признака: 'беспомощность перед искушением' (33 \%), 'первоначальность' $(28,5 \%)$. Такой признак, как 'нагота', обнаруживается в коллективном когнитивном пространстве англоязычных респондентов, но занимает периферийное положение $(9,5 \%)$. К другим периферийным признакам данных прецедентных антропонимов представляется возможным отнести 'гетеросексуальность' (9,5 \%), 'предначертание быть наказанными' (9,5 \%), 'возможность получить прозрение' (5 \%), 'способность испытывать сильные эмоции’ (5 \%).

На этапе коннотативного употребления может проявляться аксиологическая составляющая концепта прецедентного антропонима. Аксиологическая маркированность, или аксиологический вектор (оценки), является важным элементом когнитивной структуры любого прецедентного феномена [Карасик, Слышкин, 2011, с. 267]. В результате опроса испытуемых были выявлены прецедентные антропонимы, связанные либо с положительным, либо с отрицательным аксиологическим вектором. Заметим, что не все прецедентные антропонимы, исследованные в ходе эксперимента, имели стабильный аксиологический вектор. Употребление некоторых прецедентных антропонимов в одних предложениях было окрашено положительно (Неразделимы как Адам и Ева), а в других отрицательно (Они были глупы как Адам и Ева). Итак, коннотативное употребление прецедентных антропонимов актуализирует их когнитивную структуру, включающую дифференциальные признаки (инвариантые и вариативные) и аксиологический вектор (стабильную или вариативную оценку).

3. Этап преобразования внешней формы (словообразование и деонимическая конверсия). Корпус прецедентных феноменов всегда подвержен изменениям. Некоторые из них теряют значимость для того или иного лингвокультурного сообщества, вследствие этого они утрачивают свой прецедентный характер и переходят в разряд архаизмов (см. об этом: [Карасик, Слышкин, 2011, с. 267]). В то же время появляются новые языковые единицы, которые входят в коллективное когнитивное пространство и приобретают прецедентный статус. Словообразование является продуктивным способом пополнения словаря прецедентных феноменов. Особого интереса заслуживает деонимическая конверсия - «бессуффиксальный переход прецедентного имени в класс глаголов» [Степанов, 2017, с. 80]. Действительно, в ответах испытуемых были отмечены случаи употребления прецедентных антропонимов как глаголов: to Tom Sawyer "to make somebody do your own work by means of deception"; to be Tom Sawyered by someone "to be deceived by someone". Употребление прецедентного антропонима в страдательном залоге усиливает негативное воздействие, которое оказывается на субъект. Возможность конверсии прецедентных антропонимов, которая была выявлена в результате опроса респондентов, подтверждается и примерами употребления данного прецедентного имени в аналогичном значении в речи современной американской молодежи: You totally Tom Sawyered that dumbass! (Urban Dictionary); I Tom-Sawyered Elaina into chopping an onion for me. She used her lab goggles and a scarf to ward off tears (Twitter) (подробно такие примеры анализируются в: [Золотарев, 2017, с. 133]). Очевидно, что английский язык, как язык аналитического типа, допускает подобные конверсионные парообразования. Приведем еще примep: Metallica really eminem'd on their new record (Urban Dictionary). Концептуальное наполнение прецедентного антропонима наблюдается и в следующем случае: What are you doing? Just bondin', you know, где to bond «шпионить, играть в Бонда» (Urban Dictionary). Во флективном русском языке такого рода примеры - большая редкость. Однако среди ответов русскоязычных респондентов оказался следующий интересный контекст: $T b l$ mym не тимати́! От имени известного репера образован глагол, смысл которого можно свести к фразе «не говори ерунды» [Золотарев, 2016, c. 116]. 
Таким образом, в ответах респондентов обнаруживаются примеры, подтверждающие популярность модели деонимической конверсии прецедентных антропонимов, при которой прецедентное имя может трансформироваться в глагол с закреплением определенного значения.

4. Этап метафоризации и метонимизации на основе развития дифференциальных признаков. В качестве иллюстрации рассмотрим случаи употребления прецедентных имен собственных для «метафорической характеристики» (подробно такие антропонимы характеризуются в: [Нахимова, 2010, с. 12]), например: $H y$, что ты его боишься, как Буратино огня?; Сгоришь как Буратино; She is hard working as Cinderella. В сравнительных конструкциях актуализируются определенные атрибуты прецедентных антропонимов, связанные, как правило, с внешним видом или образом. Например, у прецедентного антропонима Буратино подобным атрибутом для многих респондентов был длинный нос: У него длинный нос, как у Буратино; Всюду суешь свой нос как Буратино. Атрибутом персонажа Cinderella является такая характеристика, как трудолюбие. Образ реального человека, чье имя стало прецедентным, или образ персонажа всегда достаточно информативен, поскольку содержит такие дифференциальные характеристики, как особенности внешнего вида, вербальное и невербальное поведение (жесты, мимика). Процесс метонимизации знания проявляется, например, в следующем контексте: он шифруется как Штирлиц.

5. Этап фразеологизации и идиоматизации. Развитие когнитивного потенциала имени собственного приводит к тому, что некоторое знание о нем может фиксироваться. Так, в процессе фразеологизации прецедентный антропоним участвует в генерации нового знания с последующим закреплением этого знания. В ответах респондентов, полученных в ходе психолингвистического эксперимента, были отмечены примеры, свидетельствующие о том, что в современном дискурсе самые популярные прецедентные антропонимы могут становиться частью устойчивого выражения.

В ответах англоязычных информантов зафиксированы случаи фразеологизации пре- цедентного имени Tom Sawyer: The secret of effective management is to pull a Tom Sawyerto convince people that doing work was their own idea. Выражение to pull a Tom Sawyer используется в приведенном контексте в значении «путем обмана пытаться заставить человека выполнить какую-либо работу». В примерах из разговорного дискурса также встречается идиоматическая фраза to pull a Tom Sawyer: You trying to pull a Tom Sawyer on me, sonny! (Tapply, 2005, p. 8); I said, 'Ned are you trying to pull a Tom Sawyer on? We are not going to fall for it'(Leibig, 2003, p. 44); No, and don't try to pull a Tom Sawyer on me neither, J.T. (Guess, 2011, p. 59). Примеры с именем Tom Sawyer не исключительны. Так, в лингвострановедческом словаре «Жизнь и культура США» представлен фразеологизм, образованный на основе имени одного из авторов американской Декларации независимости: Put your John Hankock here «распишись, поставь свою крупную подпись» (Жизнь и культура США, с. 202). Тенденцию к идиоматизации прецедентного антропонима обнаруживает имя James Bond, которое используется в устойчивом словосочетании James bond a horse «не знаю, что и сказать, просто нет слов»: Can someone tell me how to defeat the final boss? You have to get the ancient weapon and then james bond a horse (Urban Dictionary), a также имя российской телеведущей О. Бузовой: «Бузовщчина года»: В этом году артистка успела: запустить «бузкойн», открыть два ресторана, стать звездой телешоу «Замуж за Бузову» (Комсомольская правда, 2018). Индивидуализированные установки и ценности отдельной личности могут выступать как референциальные признаки имени собственного, образуя устойчивое словосочетание на основе прецедентного имени: познеровский патриотизм, познеровская прав$\partial a$. Как видим, некая прецедентная ситуация, известная в определенной этнолингвокультуре, становится настолько часто повторяющейся, что прецедентный антропоним, актуализирующий ее, фразеологизируется.

6. Этап языковой игры. Приемом языковой игры можно считать употребление прецедентного онима, основанное на созвучии формы прецедентного имени с другими словами. Например: Would you Adam and Eve it? 
Здесь использовано созвучие слов: Eve (Ева) и глагола to believe (верить). В русском языке такого созвучия не существует, поэтому при переводе языковая игра теряется. Новое значение у словосочетания Adam and Eve было впервые зафиксировано в рифмованном сленговом выражении на диалекте Кокни, который используется некоторыми жителями Лондона (Dictionary of Cockney Rhyming Slang, p. 9). Употребление прецедентного антропонима Adam and Eve в качестве глагола давно вышло за пределы лондонского диалекта и стало широко известно в англоговорящем мире. Простая верификация в виде запроса в поисковой системе Интернет дает большое количество случаев употребления данной фразы как в социальных сетях, так и в медийном дискурсе, например: Would you Adam and Eve it? New castle double their lead as Muto collects Shelvey's cross in the box and turns Young almost in slow motion before fizzing a finish past De Gea (The Telegraph, 2018). В подобных случаях собственный когнитивный потенциал прецедентного антропонима остается невостребованным, поскольку не происходит реализации такого главного свойства прецедентности, как референциальность.

Включение прецедентных антропонимов в языковую игру раскрывает новое качество прецедентности - быть маркером развитости языковой компетенции говорящего. Цель языковой игры - передать не информацию о сообщаемом событии в строгом смысле, а информацию о намерениях и интенциях говорящего, которые могут сводиться к желанию внести разнообразие в банальное бытовое общение. Нередко подобная языковая игра призвана показать эрудицию говорящего, талант к остроумию или его способности к лингвокреативности. Умение использовать прецедентные феномены в игровой (людической) функции говорит о высоком уровне развития языковой компетенции говорящего.

\section{Выводы}

Анализ прецедентного имени в аспекте развития его когнитивного потенциала ранее в отечественной лингвистике не проводился, хотя имена собственные реализуют особые принципы номинации и механизмы концепту- ализации знаний, а трансформация имени собственного в прецедентный антропоним представляет собой оригинальную модель формирования вторичного концептуального знания. Динамическое развитие знания, репрезентируемого прецедентной единицей, - это сложный предмет для исследования, поэтому нами была использована комплексная методика сбора материала, включающая анализ лексикографических, дискурсивных источников, а также ответов респондентов, полученных в ходе психолингвистического эксперимента.

Концептуальную эволюцию прецедентного антропонима предопределяют его особенности. Уникальность имени собственного состоит в том, что основная информация сконцентрирована не в денотативном, а в коннотативном значении. Оно отражено в наборе дифференциальных признаков, и именно его предлагается трактовать как инвариант восприятия, который хранится в когнитивной базе. Имя собственное само по себе малоинформативно, но оно становится узнаваемым и воспроизводимым при наличии дифференциальных признаков. Последние образуют когнитивное пространство, динамика которого проявляется в возможности слияния концептов и появлении новых значений. Дифференциальные признаки аксиологически и национально-культурно маркированы, то есть совокупность знаний содержит оценку и информацию, которая может быть известна представителям только одного этнолингвокультурного сообщества. Развитие когнитивного потенциала прецедентного антропонима в дискурсивной практике осуществляется в шесть этапов: денотативное употребление; коннотативное употребление; преобразование внешней формы (словообразование, деонимическая конверсия); метафоризация и метонимизация; фразеологизация и идиоматизация; языковая игра. Таким образом, некая совокупность знаний об объекте может приобретать дополнительные смыслы в процессе функционирования языковой единицы в конкретных лингвопрагматических ситуациях с учетом национально-культурных особенностей.

Имя собственное, получившее прецедентный статус, становится особым лингвоментальным комплексом, а отличительной чертой концепта имени собственного является способ- 
ность к приращению дополнительных знаний, или к развитию когнитивного потенциала.

\section{СПИСОК ЛИТЕРАТУРЫ}

Волкова П. С., 2017. Язык и речь в пространстве культуры: интерпретация и реинтерпретация // Вестник Волгоградского государственного университета. Серия 2, Языкознание. Т. 16. № 4. С. 207-214. DOI: https://doi.org/10.15688/jvolsu2.2017.4.20.

Гудков Д. Б., 1998. Прецедентное имя в когнитивной базе современного русского (результаты эксперимента) // Язык, сознание, коммуникация : сб. ст. / под ред. В. В. Красных, А. И. Изотова. М. : Филология. Вып. 4. С. 82-93.

Золотарев М. В., 2017. Лингвопрагматические особенности прецедентных феноменов в современном молодежном дискурсе (на материале английского и русского языков) : дис. ... канд. филол. наук. Саратов. 176 с.

Золотарев М. В., 2016. Коннотация прецедентных имен «Eminem» и «Тимати» в американской и русской лингвокультурах // Филологические науки. Вопросы теории и практики. № 1-1 (55). C. $115-118$.

Карасик В. И., Слышкин Г. Г., 2011. Прецедентные онимы в СМИ // Политическая лингвистика. № 3 (37). С. 266-268.

Красных В. В., 2003. Свой среди чужих: миф или реальность? М. : Гнозис. 375 с.

Кубрякова Е. С., 1997. Концепт // Краткий словарь когнитивных терминов / под ред. Е. С. Кубряковой. М. : МГУ. С. 89-92.

Ларина Т. Ю., Милевская Т. В., 2015. Роль имен собственных в формировании когерентного текста (на материале романов И. Ильфа и Е. Петрова «Двенадцать стульев» и «Золотой теленок») // Вестник Волгоградского государственного университета. Серия 2, Языкознание. Т. 14, № 5. C. 114-119. DOI: http://dx.doi. org/10.15688/jvolsu2.2015.5.13.

Нахимова Е. А., 2010. Аспекты когнитивного исследования использования имени собственного // Вопросы когнитивной лингвистики. № 2. C. $12-17$.

Прецедентное имя и прецедентное высказывание как символы прецедентных феноменов, 1997 / И. В. Захаренко [и др.] // Язык, сознание, коммуникация : сб. ст. / под ред. В. В. Красных, А. И. Изотова. М. : Филология. Вып. 1. С. 82-103.

Привалова И. В., 2005. Интеркультура и вербальный знак. М. : Гнозис. 472 с.

Терещенко А. В., 2016. Прецедентные имена в современном русском и английском языках: ста- тус, семантика, особенности функционирования // Вестник ТГПУ. № 11 (176). С. 76-84.

Степанов Е. С., 2017. Образование деонимических деривативов от прецедентных имен в немецком языке // Вестник ТГПУ. № 6 (183). С. 80-84. DOI: https://doi.org/10.23951/1609-624X-2017-680-84.

Schaarschmidt G., 2018. Some Good Reasons for Renaming Places, and Some not so Good Ones: a Cross-Cultural Sketch. In Honour of Canada's $150^{\text {th }}$ Birthday and the Year of Reconciliation // Вопросы ономастики. Т. 15, № 1. C. 181-187. DOI: https://doi.org/10.15826/ vopr_onom.2018.15.1.009.

\section{ИСТОЧНИКИ}

Комсомольская правда. URL: https://www.saratov. bkp.ru/daily/26927.7/3974463 (дата обращения: 09.01.2019).

Guess B., Kumpel. Bloomington, IN : iUniverse, 2011. $196 \mathrm{p}$.

Leibig M. Travelling in Disguise. Dungannon, VA, Creeekside Press, 2003. 116 p.

Tapply W. G. Bitch Creek. Guilfford, Connecticut : The Lyons Press, 2005. 304 p.

The Guardian. 2016. URL: https://www.theguardian.com/ world/2016/jan/19/terrorism-act-incompatible-withhuman-rights-court-rules-in-david-miranda-case (date of access: 18.01.2019).

The Guardian. 2018. URL: https://www.theguardian.com/ music/2018/sep/04/paul-bunyan-review-enobritten-wiltons-music-hall (date of access: 19.01.2019).

The Telegraph. 2018. URL: https://www.telegraph.co.uk/ football/2018/10/06/manchester-united-vsnewcastle-live-score-latest-jose-mourinho (date of access: 23.01.2019).

Twitter. URL: https://twitter.com/Popehat (date of access: 23.01.2019).

\section{СЛОВАРИ}

Американа - Англо-русский лингвострановедческий словарь «Американа» / под ред. Г. В. Чернова. Смоленск ; М. : Полиграмма, 1996. 1186 с.

Жизнь и культура США - Жизнь и культура США. Лингвострановедческий словарь / О. А. Леонтович, Е. И. Шейгал. 2-е изд. Волгоград : Станица, 2000. 416 c.

Русское культурное пространство - Русское культурное пространство. Лингвокультурологический словарь / И. С. Брилева, Н. П. Вольская, Д. Б. Гудков, И. В. Захаренко, В. В. Красных. М. : Гнозис, 2004. Вып. 1. 318 с. 
A Dictionary of Cockney Rhyming Slang. [S. 1.] : Watchya.com Publications, 2010. $77 \mathrm{p}$.

Urban Dictionary. URL: https://www.urbandictionary. com (date of access: 23.01.2019).

\section{RFERENCES}

Volkova P.S., 2017. Yazyk i rech v prostranstve kultury: interpretatsiya i reinterpretatsiya [Language and Speech in the Space of Culture: Interpretation and Reinterpretation]. Vestnik Volgogradskogo gosudarstvennogo universiteta. Seriya 2, Yazykoznanie [Science Journal of Volgograd State University. Linguistics], vol. 16, no. 4, pp. 207-214. DOI: https://doi.org/10.15688/ jvolsu2.2017.4.20.

Gudkov D.B., 1998. Pretsedentnoe imya v kognitivnoy baze sovremennogo russkogo (rezultaty eksperimenta) [Precedent Name in the Cognitive Base of the Contemporary Russian Language (Experiment Findings)]. Yazyk, soznanie, kommunikatsiya: sb. st. [Language, Consciousness, Communication. Collected Articles]. Moscow, Filologiya Publ., iss. 4, pp. 82-93.

Zolotarev M.V., 2017. Lingvopragmaticheskie osobennosti pretsedentnykh fenomenov $v$ sovremennom molodezhnom diskurse (na material angliyskogo i russkogo yazykov): dis.... kand. filol. nauk [Linguistic and Pragmatic Features of Precedent Phenomena in Modern Youth Discourse (Based on the English and Russian Languages). Cand. philol. sci. diss.]. Saratov. $176 \mathrm{p}$.

Zolotarev M.V., 2016. Konnotatsiya pretsedentnykh imen «Eminem» $\mathrm{i}$ «Timati» v amerikanskoy $\mathrm{i}$ russkoy lingvokulturakh [Connotation of Precedent Names "Eminem" and "Timati" in American and Russian Linguocultures]. Filologicheskie nauki. Voprosy teorii i praktiki [Philological Sciences. Issues of Theory and Practice], no. 1-1(55), pp. 115-118.

Karasik V.I., Slyshkin G.G., 2011. Pretsedentnye onimy v SMI [Precedent Onims in Media]. Politicheskaya lingvistika [Political Linguistics], no. 3(37), pp. 266-268.

Krasnykh V.V., 2003. Svoy sredi chuzhikh: mif ili realnost? [At Home Among Strangers: Myth or Reality?]. Moscow, Gnozis Publ. 375 p.

Larina T.Yu., Milevskaya T.V., 2015. Rol imen sobstvennykh $\mathrm{v}$ formirovanii kogerentnogo teksta (na material romanov I. Ilfa i E. Petrova «Dvenadt satstulyev» i «Zolotoy telenok») [Proper Names and Their Functions in the Text Coherency Formation (At the Material of the Novels "The Twelve Chairs" and "The Little Golden Calf" by I. Ilf and E. Petrov). Vestnik Volgogradskogo gosudarstvennogo universiteta. Seriya 2, Yazykoznanie [Science Journal of Volgograd State University. Linguistics], vol. 14, no. 5, pp. 114119. DOI: http://dx.doi.org/10.15688/jvolsu2. 2015.5.13.

Nakhimova E.A., 2010. Aspekty kognitivnogo issledovaniya ispolzovaniya imeni sobstvennogo [Aspects of Cognitive Research on the Use of Proper Names]. Voprosy kognitivnoy lingvistiki [Issues of Cognitive Linguistics], no. 2, pp. 12-17.

ZakharenkoI.V., Krasnykh V.V., GudkovD.B., Bagaeva D.V., 1997. Pretsedentnoe imya i pretsedentnoe vyskazyvanie kak simvoly pretsedentnykh fenomenov [Precedent Name and Precedent Saying as Symbols of Precedent Phenomena]. Krasnykh V.V., Izotov A.I., eds. Yazyk, soznanie, kommunikatsiya: sb. st. [Language, Consciousness, Communication. Collected Articles]. Moscow, Filologiya Publ., iss. 1, pp. 82-103.

Privalova I.V., 2005. Interkultura i verbalnyy znak [Interculture and Verbal Sign]. Moscow, Gnozis Publ. 472 p.

Tereshchenko A.V., 2016. Pretsedentnye imena v sovremennom russkom i angliyskom yazykakh: status, semantika, osobennosti funktsionirovaniya [Precedent Names in Modern Russian and English Languages: Status, Semantics, Functioning Pecularities]. Vestnik TGPU [Tomsk State Pedagogical University Bulletin], no. 11 (176), pp. 76-84.

Stepanov E.S., 2017. Obrazovanie deonimicheskikh derivativov ot pretsedentnykh imen $\mathrm{v}$ nemetskom yazyke [Deonymic Derivation from Precedent Names in German]. Vestnik TGPU [Tomsk State Pedagogical University Bulletin], no. 6(183), pp. 80-84. DOI: https://10.23951/1609624X-2017-6-80-84.

Schaarschmidt G.,2018. Some Good Reasons for Renaming Places, and Some not so Good Ones: A Cross-Cultural Sketch. In Honour of Canada's $150^{\text {th }}$ Birthday and the Year of Reconciliation. Problems of Onomastics, vol. 15 , no. 1, pp. 181-187. DOI: 10.15826/vopr_ onom.2018.15.1.009.

\section{SOURCES}

Komsomolskaya pravda. URL: https://www.saratov. kp.ru/daily/26927.7/3974463 (accessed 9 January 2019). 
Guess B. Kumpel. Bloomington, IN, iUniverse, 2011. $196 \mathrm{p}$.

Leibig M. Travelling in Disguise. Dungannon, Creeekside Press, 2003. 116 p.

Tapply W.G. Bitch Creek. Guilfford, Connecticut, The Lyons Press, 2005. 304 p.

The Guardian. 2016. URL: https:/www.theguardian.com/ world/2016/jan/19/terrorism-act-incompatible-withhuman-rights-court-rules-in-david-miranda-case (accessed 18 January 2019).

The Guardian. 2018. URL: https:/www.theguardian.com/ music/2018/sep/04/paul-bunyan-review-enobritten-wiltons-music-hall (accessed 19 January 2019).

The Telegraph. 2018. URL: https://www.telegraph.co.uk/ football/2018/10/06/manchester-united-vsnewcastle-live-score-latest-jose-mourinho/ (accessed 23 January 2019).

Twitter. URL: https://twitter.com/Popehat (accessed 23 January 2019).

\section{DICTIONARIES}

Chernova G.V., ed. Anglo-russkiy lingvostranovedcheskiy slovar "Amerikana» [Americana English-Russian Encyclopedic Dictionary]. Smolensk, Moscow, Poligramma Publ. 1186p.

Leontovich O.A., Sheigal E.I. Zhizn i kultura SShA. Lingvostranovedcheskiy slovar [Life and Culture of the USA. Encyclopedic Dictionary]. Volgograd, Stanitsa Publ., 2000. $416 \mathrm{p}$.

Brileva I.S., Volskaya N.P., GudkovD.B., Zakharenko I.V., Krasnykh V.V. Russkoe kulturnoe prostranstvo. Lingvokulturologicheskiy slovar [Russian Cultural Space. Linguocultural Dictionary]. Moscow, Gnozis Publ., 2004, iss. 1. 318 p.

A Dictionary of Cockney Rhyming Slang. Watchya.com Publicatons, 2010. 77 p.

Urban Dictionary. URL: https://www.urbandictionary. com (accessed 23 January 2019).

\section{Information About the Authors}

Mikhail V. Zolotarev, Candidate of Sciences (Philology), Associate Professor, Department of English and English Teaching Methods, Saratov State University named after N.G. Chernyshevsky, Astrakhanskaya St., 83, 410004 Saratov, Russia, mizrkb@gmail.com, https://orcid.org/0000-0002-1209-4759

Irina V. Privalova, Doctor of Sciences (Philology), Professor, Department of Russian and Latin Languages, Saratov State Medical University named after V.I. Razumovsky, Bolshaya Kazachya St., 112, 410012 Saratov, Russia, ivprivalova@mail.ru, https://orcid.org/0000-0002-7740-2185

\section{Информация об авторах}

Михаил Владимирович Золотарев, кандидат филологических наук, доцент кафедры английского языка и методики его преподавания, Саратовский национальный исследовательский государственный университет им. Н.Г. Чернышевского, ул. Астраханская, 83, 410004 г. Саратов, Россия, mizrkb@gmail.com, https://orcid.org/0000-0002-1209-4759

Ирина Владимировна Привалова, доктор филологических наук, профессор кафедры русского и латинского языков, Саратовский государственный медицинский университет им. В.И. Разумовского, ул. Большая Казачья, 112, 410012 г. Саратов, Россия, ivprivalova@mail.ru, https://orcid.org/0000-0002-7740-2185 